\title{
Variations in $\mathrm{Cd}$ and $\mathrm{Pb}$ Accumulations of Hot Pepper (Capsicum annuum L.) Cultivars for Screening Pollution- and Nitrate-Safe Cultivars
}

\author{
Li Chen ${ }^{1}$, Zheng-Xu Cui ${ }^{2}$, Dan Wang ${ }^{1,2 *}$ \\ ${ }^{1}$ College of Life Science and Engineering, Southwest University of Science and Technology, Mianyang, China \\ ${ }^{2}$ State Defense Key Laboratory of Nuclear Waste and Environmental Security, Southwest University \\ of Science and Technology, Mianyang, China
}

Received: 21 August 2019

Accepted: 15 October 2019

\begin{abstract}
Screening pollution-safe cultivars has become one of the most direct and cost-effective methods for reducing metals entering the food chain. The aims of this study were to screen low $\mathrm{Cd}$ and $\mathrm{Pb}$ hot pepper cultivars and clarify the mechanisms of low $\mathrm{Cd}$ and $\mathrm{Pb}$ accumulation in fruits. In this study, we found that fruit $\mathrm{Cd}$ and $\mathrm{Pb}$ concentrations were significantly different $(p<0.05)$ among cultivars and were also significantly $(p<0.05)$ affected by $\mathrm{Cd}$ and $\mathrm{Pb}$ levels. Meanwhile, fruit $\mathrm{Cd}$ and $\mathrm{Pb}$ concentrations are significantly positively correlated with both the shoot $\mathrm{Cd}$ and $\mathrm{Pb}$ concentrations and the translocation factors. Nevertheless, there were no significant $(p<0.05)$ correlations between the fruit $\mathrm{Cd}$ and $\mathrm{Pb}$ concentrations and the root $\mathrm{Cd}$ and $\mathrm{Pb}$ concentrations. Two hot pepper cultivars, Nos. 8 (Youma) and 11 (Xianglaerjintiao), were identified as low $\mathrm{Cd}$ and $\mathrm{Pb}$ cultivars. The nitrate content of No. 11 (Xianglaerjintiao) exceeded $440 \mathrm{mg} \cdot \mathrm{kg}^{-1} \mathrm{FW}$ in $\mathrm{T} 2$ treatment, thus the No. 8 (Youma) can be grown to increase agricultural food safety compared to the No. 11 (Xianglaerjintiao). Therefore, the No. 8 (Youma) is suitable to be planted in low $\mathrm{Cd}$ - and Pb-contaminated soils for screening pollution-safe cultivars.
\end{abstract}

Keywords: cadmium and lead, hot pepper, nitrate content, translocation, low $\mathrm{Cd}$ and $\mathrm{Pb}$ cultivars

\section{Introduction}

Heavy metals (HMs) pollution in agricultural soil has become a worldwide environmental problem, because the HMs easily accumulate in soil and pose a great threat to the ecosystem, agro-system, and people's health [1-3]. Among HM-contaminated soils, cadmium $(\mathrm{Cd})$ and lead $(\mathrm{Pb})$ contamination in soils have been a worldwide environmental problem, especially in China [4], owing to exploitation and smelting of mines, deposition, sewage discharge, and the excessive use of fertilizers [5]. For example, $\mathrm{Cd}$ and $\mathrm{Pb}$ in the percentage 
of soil samples (7.0\% and $1.5 \%)$ exceed the Ministry of Environmental Protection limit in China [4]. Crops are the main source of $\mathrm{Cd}$ and $\mathrm{Pb}$ entering the human body. Therefore, screening low heavy metals $(\mathrm{Cd}$ and $\mathrm{Pb}$ ) levels in the edible part of crops is a practical technique for reducing the health risks of heavy metalcontaminated soil.

The remediation contaminated by HMs has been reported by many researchers, such as adsorption, leaching, and electrokinetic remediation [6-8]. However, these techniques have some disadvantages in practice such as slow process, high cost, and damage of soil structure. The cycle of phytoextraction is also too long to quickly amend many metals-polluted soils. Furthermore, it is difficult for farmers to fallow the farmland for soil remediation, because the demand of farmers to produce food is quite high, especially in China. Thus, the screening crop cultivars of low HMs have been proposed by several researchers, which is an effective method to reduce ecological risks of heavy metals-contaminated soils $[9,10]$. In past years, researchers found that the accumulation and distribution of $\mathrm{HMs}$ (including $\mathrm{Cd}$ and $\mathrm{Pb}$ ) varied largely not only among crop species but also among cultivars [11, 12]. Many low $\mathrm{Cd}$ and $\mathrm{Pb}$ accumulation cultivars were selected from different crops such as Chinese cabbage [12], maize [13], wheat [15], pakchoi [16], and so on. Based on these studies, the investigations of pollutionsafe crop cultivars in HM-contaminated soils have been a concern of researchers [17, 18].

At present, many researchers have reported that the transport processes mediating $\mathrm{Cd}$ and $\mathrm{Pb}$ accumulation in phytoremediation, which includes the absorption of $\mathrm{Cd}$ and $\mathrm{Pb}$ by roots, $\mathrm{Cd}$ and $\mathrm{Pb}$ translocation from the root to the aboveground parts, and xylem-to-phloem $\mathrm{Cd}$ and $\mathrm{Pb}$ transfer [19-21]. In addition, a few portions of $\mathrm{Cd}$ and $\mathrm{Pb}$ are translocated from the roots to the edible plant parts, for example fruits. The $\mathrm{Cd}$ and $\mathrm{Pb}$ levels of edible plant parts may be influenced by several physiological and biochemical features of the different species. Liu et al. [13] found that the edible parts of Lvxing 70 and Dongchu have the lowest and highest $\mathrm{Cd}$ accumulation properties in the 12 cabbage genotypes, respectively. Liu et al. [15] have also confirmed that wheat cultivar LF-13 showed the lowest $\mathrm{Cd}$ and $\mathrm{Pb}$ accumulation characteristics in their shoots among 30 wheat cultivars. Meanwhile, vegetables are a crop that is accumulated to nitrates easily, which may be related to their nutritional properties [22]. The study showed that $72-94 \%$ nitrates entering the human body are derived from vegetables, and excess nitrate content causes adverse effects on the human body [23, 24]. Therefore, the nitrate content of vegetables has become an important indicator to measure the health and safety of vegetables.

Hot pepper, a fruit vegetable with a more than 9000 -year history, is widely cultivated in southern China. In 2015, the cultivated area in China is about 1.47 million $\mathrm{hm}^{2}$, with 28 million tons of production.
Previous studies have shown that hot pepper can easily absorb and accumulate $\mathrm{HMs}$ (including $\mathrm{Pb}$ and $\mathrm{Cd}$ ) from soils, which may cause adverse health effects [25]. Therefore, the screening of hot pepper cultivars with low $\mathrm{Cd}$ and $\mathrm{Pb}$ accumulation can reuse the contaminated soils and produce safe hot peppers in southern China.

Agricultural land has been widely polluted by HMs due to industrial activities, municipal sewage irrigation, and waste disposal practices in the industrial city of China. Thus, the aim of this study was to reduce the agricultural food risks through screening low accumulation cultivars in the $\mathrm{Cd}$ - and $\mathrm{Pb}$-contaminated soil. The objectives were to: (1) determine the variety of biomass and nitrate content in hot pepper fruits, (2) screen low $\mathrm{Cd}$ and $\mathrm{Pb}$ concentrations from the tested the edible parts of hot pepper cultivars, and (3) investigate the differences in the uptake, translocation, and accumulation of $\mathrm{Cd}$ and $\mathrm{Pb}$ in hot pepper cultivars to clarify the mechanisms of low $\mathrm{Cd}$ and $\mathrm{Pb}$ accumulation in hot pepper fruits.

\section{Materials and Methods}

\section{Hot Pepper and Soil Materials}

Hot pepper (Capsicum annuum L.) cultivar seeds (Table 1) were purchased from the agricultural wholesale market of Fucheng District (Mianyang City, Sichuan Province, China). The soil samples (yellow earth) were selected from the topsoil $(0-24 \mathrm{~cm})$ in Longshan Garden of the Southwest University of Science and Technology. The basic physicochemical properties of the soil were as follows: $\mathrm{Cd}$ and $\mathrm{Pb}$ concentrations were $0.24 \mathrm{mg} \cdot \mathrm{kg}^{-1}$ and $28.12 \mathrm{mg} \cdot \mathrm{kg}^{-1}, \mathrm{pH}$ was 6.88 , organic substances content was $18.99 \mathrm{~g} \cdot \mathrm{kg}^{-1}$, cation exchange capacity was $115.64 \mathrm{mmol} \cdot \mathrm{kg}^{-1}$, and the concentrations of available phosphorous, alkali-hydrolysable nitrogen, and available potassium were 41.35, 166.46 and $57.03 \mathrm{mg} \cdot \mathrm{kg}^{-1}$, respectively.

\section{Experimental Design}

$\mathrm{Cd}$ - and $\mathrm{Pb}$-contaminated soil were simulated in a greenhouse pot experiment by air-drying the test soil (yellow earth), removing the weeds and gravel and then crushing and mixing it. The soil samples $(2.5 \mathrm{~kg}$ each) were then placed in a plastic basin (diameters of $20 \mathrm{~cm}$ (top) and $16 \mathrm{~cm}$ (bottom), height of $18 \mathrm{~cm}$ ) with a hole in the bottom in a tray. $\mathrm{Cd}$ and $\mathrm{Pb}$ (control group (CK)- $0 \mathrm{mg} \cdot \mathrm{kg}^{-1} \mathrm{Cd}$ and $0 \mathrm{mg} \cdot \mathrm{kg}^{-1} \mathrm{~Pb}$; T1, $0.3 \mathrm{mg} \cdot \mathrm{kg}^{-1}$ $\mathrm{Cd}$ and $250 \mathrm{mg} \cdot \mathrm{kg}^{-1} \mathrm{~Pb}$; $\mathrm{T} 2,1.5 \mathrm{mg} \cdot \mathrm{kg}^{-1} \mathrm{Cd}$ and $1250 \mathrm{mg} \cdot \mathrm{kg}^{-1} \mathrm{~Pb}$; T3, $3.0 \mathrm{mg} \cdot \mathrm{kg}^{-1} \mathrm{Cd}$ and $2500 \mathrm{mg} \cdot \mathrm{kg}^{-1}$ $\mathrm{Pb}$ ) were added exogenously onto the soil (an aqueous solution of $\mathrm{CdCl}_{2} \cdot 2.5 \mathrm{H}_{2} \mathrm{O}$ and $\mathrm{PbSO}_{4}$ were uniformly sprayed onto the soil, respectively), and base fertilizer containing $\quad\left(\mathrm{NH}_{4}\right)_{2} \mathrm{SO}_{4} \quad\left(843.6 \quad \mathrm{mg} \cdot \mathrm{kg}^{-1}\right), \quad \mathrm{KH}_{2} \mathrm{PO}_{4}$ (337.2 $\left.\mathrm{mg} \cdot \mathrm{kg}^{-1}\right)$, and $\mathrm{K}_{2} \mathrm{SO}_{4}\left(885.7 \mathrm{mg} \cdot \mathrm{kg}^{-1}\right)$ powders was applied. The treatment soil was thoroughly stirred 
Table 1. Cultivars of tested hot peppers (Capsicum annuum L.).

\begin{tabular}{|l|l|l|l|l|l|}
\hline No. & Cultivar & No. & Cultivar & No. & Cultivar \\
\hline 1 & Huangpipaowang & 5 & Jinbaili & 9 & Guoxian2018 \\
\hline 2 & Zaozaerhao & 6 & Erjintiao & 10 & Guizuchaotianjiao \\
\hline 3 & Wuhubopijiao & 7 & Luo28tiaojiao & 11 & Xianglaerjintiao \\
\hline 4 & Qiangfeng7301 & 8 & Youma & 12 & Erhaoniujiaojiao \\
\hline 13 & Shuduhong & 14 & Zilameizi & 15 & Dahuangchaotianjiao \\
\hline
\end{tabular}

and maintained at a moisture content of $60-70 \%$ of the field moisture capacity and left to stand for 4 weeks. Subsequently, the hot pepper seedlings that had grown well and consistently were transplanted into the pots (180 pots in total) containing $\mathrm{Cd}$ - and $\mathrm{Pb}$-contaminated soil (April 12, 2018). The experiment was conducted in a completely randomized block design with triplicate pots per treatment. All treatments were performed in the greenhouse at the Laboratory of Nuclear Waste and Environmental Security in Mianyang. The moisture content in the pots was regularly adjusted to approximately $60 \%$ of the field moisture capacity, and the rest of the environmental conditions were consistently maintained. After a 3-month growing period in the pots, the hot pepper cultivars were harvested (July 12, 2018) and the measurements were taken.

\section{Measurement Methods}

\section{Biomass and Nitrate Content Measurement}

The fresh fruits of hot pepper were first harvested and weighed. The roots and shoots (exclude the fruits) were carefully removed from the soils in pots, and washed with tap water, and carefully rinsed three times with deionized water. Then all plants were separated into roots, shoots, and fruits placed in paper bags. The paper bags were dried to a constant weight at $75^{\circ} \mathrm{C}$ after $30 \mathrm{~min}$ at $105^{\circ} \mathrm{C}$, and the roots, shoots, and fruits were weighed using an electronic balance again. The fresh hot pepper fruits were weighed to $0.5100 \mathrm{~g}$ and placed in a mortar. The samples were ground and poured into a $100 \mathrm{ml}$ measuring flask with $30 \mathrm{ml}$ deionized water. The samples were treated sequentially with $5 \mathrm{ml}$ ammonia buffer ( $\mathrm{pH}=9.6), 30 \mathrm{ml}$ deionized water, and powderactivated carbon of $0.5 \mathrm{~g}$ with continuous agitation and then allowed to rest for $20 \mathrm{~min}$. The nitrate content of hot pepper fruits was determined by the spectrometer (NanoDrop 2000, Beijing Purkinje General Instrument Co., Ltd, Beijing, China) at $219 \mathrm{~nm}$.

\section{$\mathrm{Cd}$ and Pb Concentration Measurement}

The roots, shoots, and fruits were pulverized using a grinder and weighed accurately to $0.3000 \mathrm{~g}$. Then, concentrated nitric acid $(20 \mathrm{~mL})$ was added, and the samples were digested using a graphite furnace digester instrument (SH230N; Hanon Instruments, Jinan, China). After filtration, the $\mathrm{Cd}$ and $\mathrm{Pb}$ concentrations were determined using an ICP-OES (AA700; PerkinElmer, Waltham, Massachusetts, USA). $\mathrm{CdCl}_{2}$ and $\mathrm{PbSO}_{4}$ were used as standard materials for assurance control.

\section{Translocation Factor (TF)}

Translocation factor (TF) was used to evaluate the ability of hot pepper cultivars to translocate $\mathrm{Cd}(\mathrm{Pb})$ from roots to aboveground parts, and it was calculated using the following equation [26]:

Translocation factor $(\mathrm{TF})=$ the $\mathrm{Cd}(\mathrm{Pb})$ concentration of the aboveground parts $\left(\mathrm{mg} \cdot \mathrm{kg}^{-1}\right) /$ the $\mathrm{Cd}(\mathrm{Pb})$ concentration of the root $\left(\mathrm{mg} \cdot \mathrm{kg}^{-1}\right)$

\section{Safety Standard and Statistical Analysis}

The critical value of $\mathrm{Cd}$ and $\mathrm{Pb}$ in hot pepper cultivars at the safe production is $0.05 \mathrm{mg} \cdot \mathrm{kg}^{-1}$ and $0.1 \mathrm{mg} \cdot \mathrm{kg}^{-1}$ as recommended by WHO/FAO (Codex Alimentarius Commission. 2001), respectively. The Standards for nitrate content in fresh fruit vegetables is under $440 \mathrm{mg} \cdot \mathrm{kg}^{-1}$ (GB 19338-2003). All treatments were replicated three times in the experiment, all data were analyzed with Excel 2013, SPSS 23.0 and Origin 9.0 for Windows. Values are expressed as mean \pm standard deviation (SD). Differences between treatments were considered significant at $p<0.05$.

\section{Results and Discussion}

\section{Fruit Biomass}

$\mathrm{Cd}$ and $\mathrm{Pb}$ are abundant and widespread toxic elements because they have adverse effects on plant growth, morphology, physiological and biochemical process [27]. Fruit biomass is a key factor to evaluate the tolerance of hot pepper cultivars in $\mathrm{Cd}$ - and $\mathrm{Pb}$ contaminated soil. Fruit biomass (dry weight, DW) of the selected hot pepper cultivars under different $\mathrm{Cd}$ and $\mathrm{Pb}$ treatments was shown in Fig. 1. In the present study, the fruit biomass of 15 hot pepper cultivars under 


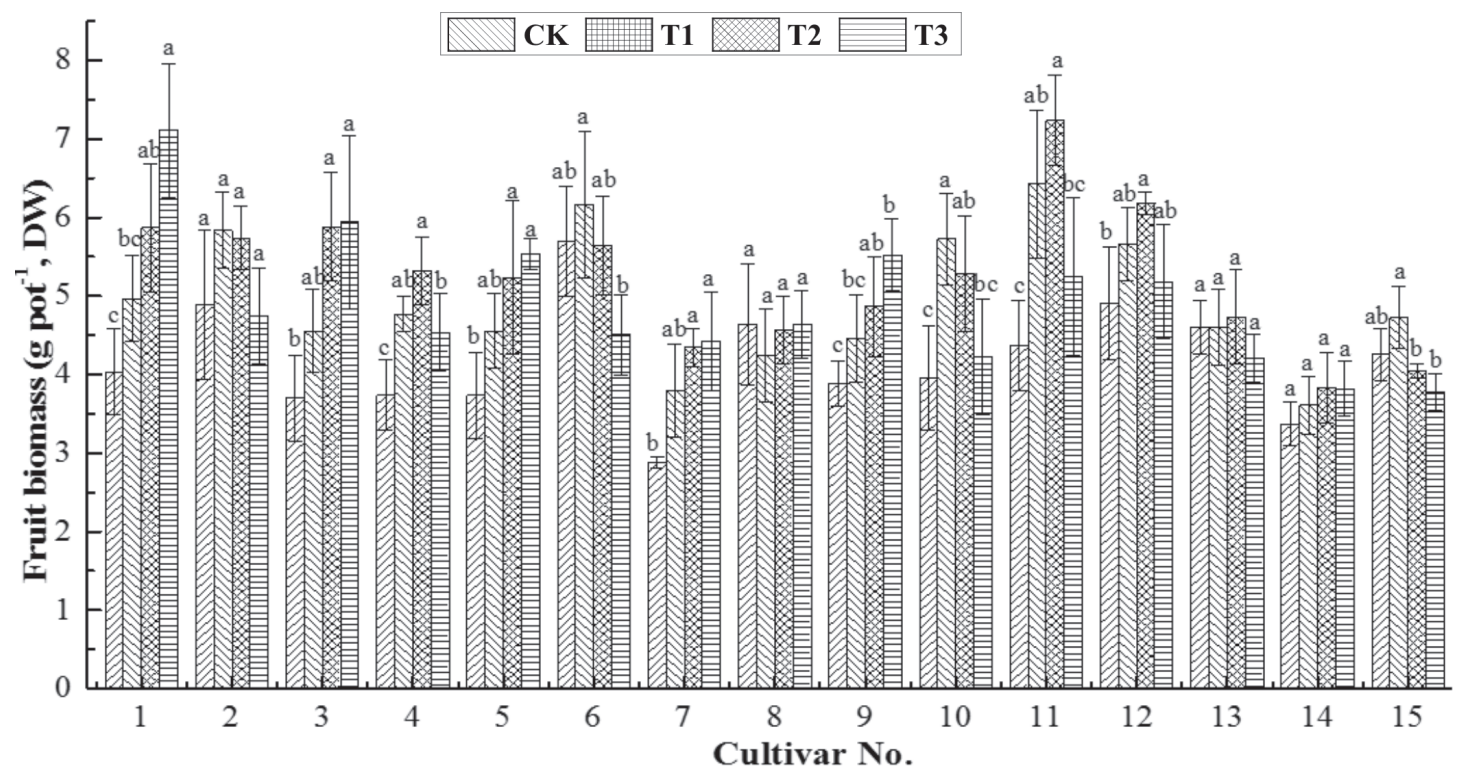

Fig. 1. Fruit biomass of hot pepper cultivars under four $\mathrm{Cd}$ and $\mathrm{Pb}$ treatments (control, $\mathrm{T} 1, \mathrm{~T} 2$ and $\mathrm{T} 3$ ); lowercase letters indicate significant differences among different treatments in identical hot pepper fruit cultivars $(p<0.05)$; total samples $\mathrm{N}=180$; replication $\mathrm{n}=3)$.

three $\mathrm{Cd}$ and $\mathrm{Pb}$ treatments (T1, T2 and T3) did not decrease more significantly than the control groups, and the biomass of the six cultivars (Nos. 1, 3, 4, 5, 7 and 9) even significantly $(p<0.05)$ increased in the T2 and T3 treatments (Fig. 1). These results indicated that hot pepper cultivars, especially the six cultivars (Nos. 1, 3, 4, 5, 7 and 9), have a higher tolerance to $\mathrm{Cd}$ and $\mathrm{Pb}$ contamination in agricultural soils compared with other crop cultivars, such as pakchoi (Brassica chinensis L.) [28], wheat (Triticum aestivum L.) [15] and tomato (Solanum lycopersicum L.) [10]. The stimulatory effect of heavy metals on plant growth may be a case of hormesis due to the physiological toxicity of heavy metals ion $[29,30]$. This is another reason for promoting the growth of plants, and it is possible that the heavy metal ion serves as an enzyme activator for the metabolism of cytokinin [31, 32].

Nevertheless, the detailed mechanisms still need to be further researched. Furthermore, all hot pepper cultivars grew well and have not reduced yield in $\mathrm{Cd}$ and $\mathrm{Pb}$ agricultural contaminated soils, which may cause farmers to think that there is not $\mathrm{Cd}$ and $\mathrm{Pb}$ toxicity in hot pepper fruits, and pose a great risk to human health through the food chain. Therefore, the selection of hot pepper cultivars with low $\mathrm{Cd}$ and $\mathrm{Pb}$ accumulation to prevent heavy metals $(\mathrm{Cd}$ and $\mathrm{Pb})$ entering the food chain is a feasible way for agricultural food safety.

\section{Nitrate Content}

Many study reports have shown that nitrate and nitrite will exert adverse effects on human health, and excess nitrate content may even cause cancer [33]. Most of the nitrates entering the human body is derived from vegetables, thus we need to regulate the nitrate content in vegetables for decreasing the potential food safety risk [34].

The nitrate content of hot pepper fruits in three $\mathrm{Cd}$ and $\mathrm{Pb}$ treatments (T1, T2 and $\mathrm{T} 3$ ) is shown in Fig. 2, which indicates that the nitrate content of hot pepper fruits under two $\mathrm{Cd}$ and $\mathrm{Pb}$ treatments ( $\mathrm{T} 2$ and T3) increased significantly $(p<0.05)$ compared to the control (Fig. 2), and that the nitrate content in T3 treatments was higher than the $\mathrm{T} 2$ treatments. Under $\mathrm{CK}$ and $\mathrm{T} 1$, the nitrate content in fruits of all hot pepper cultivars were lower than $440 \mathrm{mg} / \mathrm{kg}$ FW (GB 19338-2003). However, under T2 treatments, the nitrate content of Nos. 7, 10, 11, and 12 exceeded $440 \mathrm{mg} \cdot \mathrm{kg}^{-1}$ FW. The most nitrate content of hot pepper cultivars with $\mathrm{T} 3$ treatments were higher than $440 \mathrm{mg} / \mathrm{kg} \mathrm{FW}$, and only Nos. 2, 5 and 9 were lower than $440 \mathrm{mg} / \mathrm{kg}$ $\mathrm{FW}$. These results showed that high-level $\mathrm{Pb}$ and $\mathrm{Cd}$ concentrations ( $\mathrm{T} 3$ treatment) had a greater promotion to the nitrate content than the other treatments. Wei and Zhang [35] also found that the nitrate content in pakchoi increased significantly with the increase of heavy metals $(\mathrm{Zn}, \mathrm{Pb}$ and $\mathrm{Cd})$ concentration in soil. The possible reason is that the processes of plants absorption, translocation and utilizing nitrogen were changed in high heavy metal stress, which causes an increase of nitrate content [36]. In addition, the genotype is another reason that varied cultivars have different nitrate contents in heavy metals stress $[37,38]$.

\section{$\mathrm{Cd}$ and $\mathrm{Pb}$ Concentrations in Hot Pepper Fruits}

Significant $(p<0.05)$ differences in fruit $\mathrm{Cd}(\mathrm{Pb})$ concentration were observed among 15 cultivars in 


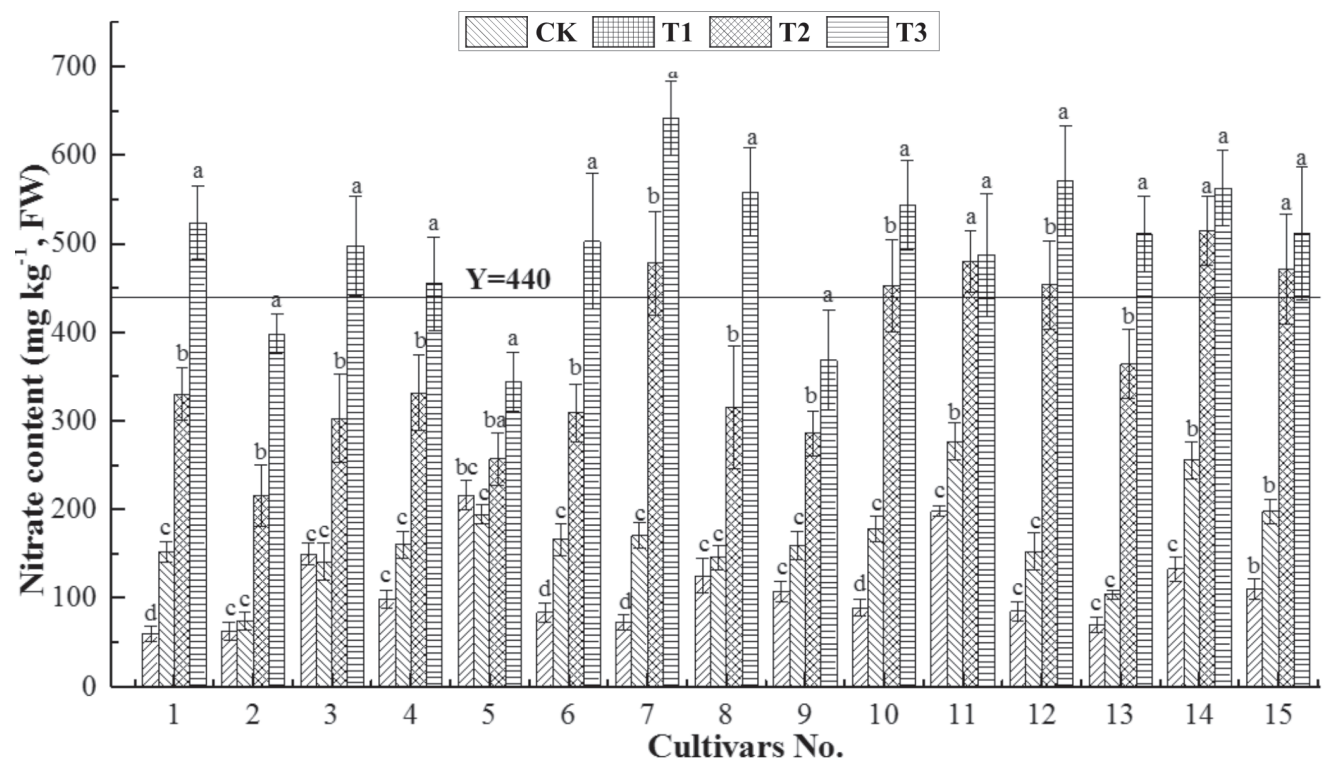

Fig. 2. Nitrate content (fresh weight, $\mathrm{FW}$ ) of hot pepper fruits under $\mathrm{Cd}$ and $\mathrm{Pb}$ treatments (control, $\mathrm{T} 1, \mathrm{~T} 2$ and $\mathrm{T} 3$ ); lowercase letters indicate significant differences among different treatments in identical hot pepper fruit cultivars $(p<0.05$; total samples $\mathrm{N}=160$; replication $n=3$ ); $Y$ line indicates the value of the standards for nitrate content.

three treatments (Table 2), ranging from $0.013(0.007)$ to 0.041 (0.023), from 0.013 (0.021) to $0.058(0.097)$, from $0.04(0.075)$ to $0.11(0.3)$, and from $0.42(1.33)$ to 0.74 (3.39), with the mean of $0.024(0.015), 0.036(0.048)$, $0.077(0.18)$ and $0.53(2.28) \mathrm{mg} / \mathrm{kg}(\mathrm{FW})$ for control, T1-, T2-, and T3 treatments, respectively. In the same four treatments (control, T1, T2 and T3), the differences between the highest and lowest $\mathrm{Cd}$ concentrations in hot pepper fruits were 3.15-, 4.46-, 2.75- and 1.76-fold, respectively. Furthermore, the fruit $\mathrm{Cd}$ concentrations in the T3 treatments were, on average, 24.33 (16.35-36.8), 17.05 (9.31-33.1) and 7.28 (4.69-11.01) times higher than the control groups, T1 treatments and T2 treatments, respectively. In this study, the fruit $\mathrm{Cd}$ concentrations of all cultivars (FW) in the control groups were lower than the Codex General Standard (2001) $\left(<0.05 \mathrm{mg} \cdot \mathrm{kg}^{-1}\right.$, FW). Under the T1 and T2 treatments, 20\% (3/15) and $80 \%(12 / 15)$ of hot pepper cultivars examined exceeded $0.05 \mathrm{mg} / \mathrm{kg} \mathrm{FW}$, respectively. However, all hot pepper cultivars examined in the T3 treatments exceeded $0.05 \mathrm{mg} / \mathrm{kg}$ FW. According to the Standard (2001), 3 hot pepper cultivars (Nos. 2, 8 and 11) were selected as low $\mathrm{Cd}$ accumulators, and the fruit $\mathrm{Cd}$ concentrations do not exceed the standard in the $\mathrm{T} 1$ and $\mathrm{T} 2$ treatments, which may engender a low risk to human health. Furthermore, Nos. 5 and 12 had higher $\mathrm{Cd}$ concentrations of hot pepper fruit compared with the other cultivars in the different treatments. By this way, 4 hot pepper cultivars (Nos. 1, 6, 8 and 11) met the standard of $\mathrm{Pb}$ concentration in hot pepper cultivar fruits $\left(<0.1 \mathrm{mg} \cdot \mathrm{kg}^{-1}, \mathrm{FW}\right)$ in the $\mathrm{T} 1$ and $\mathrm{T} 2$ treatments, and the fruit $\mathrm{Pb}$ concentrations (FW) of all the cultivars exceeded $0.1 \mathrm{mg} \cdot \mathrm{kg}^{-1}$ in the T3 treatment (Table 2). Meanwhile, compared with the other cultivars, Nos. 3 and 12 had higher fruit $\mathrm{Pb}$ concentrations in the different treatments. In addition, the $\mathrm{Cd}$ and $\mathrm{Pb}$ concentration of all hot pepper fruit cultivars exceed the Codex General Standard in T3 treatments $\left(3.0 \mathrm{mg} \cdot \mathrm{kg}^{-1} \mathrm{Cd}\right.$ and $\left.2500 \mathrm{mg} \cdot \mathrm{kg}^{-1}\right)$. Similarly, Zhang et al. [11] reported that no low $\mathrm{Cd}$ and $\mathrm{Pb}$ lettuce (Lactuca sativa L.) cultivars were found under high $\mathrm{Cd}$ $\left(1.428 \mathrm{mg} \cdot \mathrm{kg}^{-1}\right)$ and $\mathrm{Pb}\left(498.660 \mathrm{mg} \cdot \mathrm{kg}^{-1}\right)$ exposure. This might be because $\mathrm{Cd}$ and $\mathrm{Pb}$ concentration in fruits of hot pepper were determined by genotype difference and heavy metal $(\mathrm{Cd}$ and $\mathrm{Pb})$ levels [21]. Therefore, the $\mathrm{Cd}$ and $\mathrm{Pb}$ concentrations in hot pepper fruits can be used to screen low $\mathrm{Cd}$ and $\mathrm{Pb}$ cultivars in certain $\mathrm{Cd}-$ and $\mathrm{Pb}$-contaminated soils.

\section{$\mathrm{Cd}$ and $\mathrm{Pb}$ Uptake, Distribution and Translocation \\ $\mathrm{Cd}$ and $\mathrm{Pb}$ Uptake and Distribution}

The uptake and distribution of heavy metals have an important influence on the accumulation of heavy metals in edible plant parts, which have been reported for many crop cultivars $[39,40]$. In the present study, heavy metals (iron) were absorbed by the plant roots, thus many researchers investigated the root uptake ability for clarifying the differences in heavy metals accumulation among cultivars $[10,18]$. The $\mathrm{Cd}$ and $\mathrm{Pb}$ concentrations of roots, shoots (leaves and stems) and fruits (DW) of hot pepper cultivars in control, T1, T2 and $\mathrm{T} 3$ treatments are illustrated in Tables 3 and 4 . The ratios of the shoot and fruit $\mathrm{Cd}$ concentrations for the five cultivars were $3.16-4.95,4.12-8.34$ and $8.56-12.52$ in the control, T1 treatments and $\mathrm{T} 2$ treatments, respectively. The ratios of shoot and fruit $\mathrm{Cd}$ concentrations in the low Cd cultivars were significantly $(p<0.05)$ higher than the high Cd cultivars, except in the T3 treatments. 
Table 2. Concentrations of $\mathrm{Cd}$ and $\mathrm{Pb}\left(\mathrm{mg} \cdot \mathrm{kg}^{-1}, \mathrm{fw}\right)$ in fruits of hot pepper cultivars under four $\mathrm{Cd}$ and $\mathrm{Pb}$ treatments (control, T1, T2 and T3).

\begin{tabular}{|c|c|c|c|c|c|}
\hline \multicolumn{2}{|c|}{ Cultivar No. } & CK & $\mathrm{T} 1$ & $\mathrm{~T} 2$ & $\mathrm{~T} 3$ \\
\hline \multirow{2}{*}{1} & $\mathrm{Cd}$ & $0.031 \pm 0.004 b c$ & $0.041 \pm 0.004 b$ & $0.092 \pm 0.008 \mathrm{bc}$ & $0.51 \pm 0.037 \mathrm{bcd}$ \\
\hline & $\mathrm{Pb}$ & $0.013 \pm 0.002 \mathrm{fg}$ & $0.043 \pm 0.006 \mathrm{ef}$ & $0.094 \pm 0.004 \mathrm{e}$ & $2.34 \pm 0.19 \mathrm{def}$ \\
\hline \multirow{2}{*}{2} & $\mathrm{Cd}$ & $0.014 \pm 0.002 \mathrm{fg}$ & $0.013 \pm 0.002 \mathrm{e}$ & $0.042 \pm 0.006 \mathrm{fg}$ & $0.43 \pm 0.014 \mathrm{~d}$ \\
\hline & $\mathrm{Pb}$ & $0.013 \pm 0.002 \mathrm{fg}$ & $0.028 \pm 0.005 \mathrm{~g}$ & $0.21 \pm 0.021 b$ & $1.96 \pm 0.11 \mathrm{fg}$ \\
\hline \multirow{2}{*}{3} & $\mathrm{Cd}$ & $0.017 \pm 0.002 \mathrm{fg}$ & $0.023 \pm 0.004 \mathrm{~cd}$ & $0.075 \pm 0.006 \mathrm{~d}$ & $0.50 \pm 0.056 \mathrm{bcd}$ \\
\hline & $\mathrm{Pb}$ & $0.023 \pm 0.004 \mathrm{a}$ & $0.065 \pm 0.008 b$ & $0.24 \pm 0.045 b$ & $2.87 \pm 0.11 \mathrm{bc}$ \\
\hline \multirow{2}{*}{4} & $\mathrm{Cd}$ & $0.034 \pm 0.006 b$ & $0.052 \pm 0.007 \mathrm{a}$ & $0.104 \pm 0.008 \mathrm{ab}$ & $0.57 \pm 0.063 b$ \\
\hline & $\mathrm{Pb}$ & $0.018 \pm 0.002 \mathrm{bcd}$ & $0.04 \pm 0.002 \mathrm{f}$ & $0.21 \pm 0.023 b c$ & $2.24 \pm 0.4 \mathrm{ef}$ \\
\hline \multirow{2}{*}{5} & $\mathrm{Cd}$ & $0.041 \pm 0.003 \mathrm{a}$ & $0.058 \pm 0.005 \mathrm{a}$ & $0.12 \pm 0.007 \mathrm{a}$ & $0.54 \pm 0.062 b c$ \\
\hline & $\mathrm{Pb}$ & $0.017 \pm 0.002 b c$ & $0.042 \pm 0.007 \mathrm{f}$ & $0.23 \pm 0.021 \mathrm{~b}$ & $2.14 \pm 0.25 \mathrm{efg}$ \\
\hline \multirow{2}{*}{6} & $\mathrm{Cd}$ & $0.029 \pm 0.004 \mathrm{bcd}$ & $0.036 \pm 0.004 b$ & $0.085 \pm 0.012 \mathrm{~cd}$ & $0.47 \pm 0.061 \mathrm{bcd}$ \\
\hline & $\mathrm{Pb}$ & $0.012 \pm 0.003 \mathrm{~g}$ & $0.043 \pm 0.004 \mathrm{ef}$ & $0.092 \pm 0.005 \mathrm{e}$ & $1.73 \pm 0.23 \mathrm{gh}$ \\
\hline \multirow{2}{*}{7} & $\mathrm{Cd}$ & $0.019 \pm 0.005 \mathrm{ef}$ & $0.025 \pm 0.004 \mathrm{c}$ & $0.058 \pm 0.005 \mathrm{e}$ & $0.53 \pm 0.099 \mathrm{bc}$ \\
\hline & $\mathrm{Pb}$ & $0.014 \pm 0.002 \mathrm{defg}$ & $0.056 \pm 0.006 \mathrm{bcd}$ & $0.15 \pm 0.029 \mathrm{~d}$ & $2.73 \pm 0.47 \mathrm{bcd}$ \\
\hline \multirow{2}{*}{8} & $\mathrm{Cd}$ & $0.013 \pm 0.002 \mathrm{~g}$ & $0.017 \pm 0.002 \mathrm{de}$ & $0.04 \pm 0.007 \mathrm{~g}$ & $0.42 \pm 0.022 \mathrm{~d}$ \\
\hline & $\mathrm{Pb}$ & $0.007 \pm 0.001 \mathrm{~h}$ & $0.023 \pm 0.006 \mathrm{~g}$ & $0.075 \pm 0.009 \mathrm{e}$ & $1.33 \pm 0.12 \mathrm{~h}$ \\
\hline \multirow{2}{*}{9} & $\mathrm{Cd}$ & $0.026 \pm 0.003 \mathrm{~cd}$ & $0.042 \pm 0.006 \mathrm{~b}$ & $0.091 \pm 0.01 \mathrm{bc}$ & $0.70 \pm 0.049 \mathrm{a}$ \\
\hline & $\mathrm{Pb}$ & $0.012 \pm 0.002 \mathrm{~g}$ & $0.048 \pm 0.007 \mathrm{def}$ & $0.21 \pm 0.023 b c$ & $1.94 \pm 0.12 \mathrm{fg}$ \\
\hline \multirow{2}{*}{10} & $\mathrm{Cd}$ & $0.025 \pm 0.004 d$ & $0.035 \pm 0.006 \mathrm{~b}$ & $0.056 \pm 0.008 \mathrm{ef}$ & $0.56 \pm 0.079 b$ \\
\hline & $\mathrm{Pb}$ & $0.014 \pm 0.002 \mathrm{efg}$ & $0.049 \pm 0.008 \mathrm{def}$ & $0.23 \pm 0.027 \mathrm{~b}$ & $3.15 \pm 0.3 \mathrm{ab}$ \\
\hline \multirow{2}{*}{11} & $\mathrm{Cd}$ & $0.014 \pm 0.002 \mathrm{fg}$ & $0.018 \pm 0.003 \mathrm{cde}$ & $0.046 \pm 0.006 \mathrm{efg}$ & $0.50 \pm 0.086 \mathrm{bcd}$ \\
\hline & $\mathrm{Pb}$ & $0.008 \pm 0.002 \mathrm{~h}$ & $0.021 \pm 0.003 \mathrm{~g}$ & $0.092 \pm 0.009 \mathrm{e}$ & $1.93 \pm 0.19 \mathrm{fg}$ \\
\hline \multirow{2}{*}{12} & $\mathrm{Cd}$ & $0.034 \pm 0.004 \mathrm{~b}$ & $0.053 \pm 0.004 \mathrm{a}$ & $0.11 \pm 0.013 \mathrm{a}$ & $0.74 \pm 0.046 \mathrm{a}$ \\
\hline & $\mathrm{Pb}$ & $0.02 \pm 0.002 \mathrm{ab}$ & $0.097 \pm 0.004 \mathrm{a}$ & $0.3 \pm 0.038 \mathrm{a}$ & $3.39 \pm 0.29 \mathrm{a}$ \\
\hline \multirow{2}{*}{13} & $\mathrm{Cd}$ & $0.019 \pm 0.003 \mathrm{ef}$ & $0.037 \pm 0.004 b$ & $0.084 \pm 0.014 \mathrm{~cd}$ & $0.47 \pm 0.07 \mathrm{bcd}$ \\
\hline & $\mathrm{Pb}$ & $0.015 \pm 0.003 \mathrm{cdef}$ & $0.048 \pm 0.008 \mathrm{def}$ & $0.17 \pm 0.025 \mathrm{~cd}$ & $1.93 \pm 0.21 \mathrm{fg}$ \\
\hline \multirow{2}{*}{14} & $\mathrm{Cd}$ & $0.023 \pm 0.003 \mathrm{de}$ & $0.051 \pm 0.008 \mathrm{a}$ & $0.103 \pm 0.011 \mathrm{ab}$ & $0.51 \pm 0.064 \mathrm{bcd}$ \\
\hline & $\mathrm{Pb}$ & $0.017 \pm 0.002 \mathrm{bcde}$ & $0.053 \pm 0.009 \mathrm{cde}$ & $0.21 \pm 0.025 b$ & $2.06 \pm 0.33 \mathrm{fg}$ \\
\hline \multirow{2}{*}{15} & $\mathrm{Cd}$ & $0.017 \pm 0.002 \mathrm{fg}$ & $0.035 \pm 0.005 b$ & $0.076 \pm 0.01 \mathrm{~d}$ & $0.45 \pm 0.044 \mathrm{~cd}$ \\
\hline & $\mathrm{Pb}$ & $0.018 \pm 0.003 b c$ & $0.06 \pm 0.008 b c$ & $0.22 \pm 0.03 b$ & $2.5 \pm 0.24 \mathrm{cde}$ \\
\hline
\end{tabular}

Note: 1 . Data in the table is shown as mean \pm standard deviation $(n=3) ; 2$. Different letters $(a, b, c, d, e$, etc. $)$ refer to significant differences at the 0.05 level. (Total samples $\mathrm{N}=160$; Replication $\mathrm{n}=3$ )

These results indicate that $\mathrm{Cd}$ translocation from shoots to fruits is more difficult in low Cd cultivars (Nos. 2, 8 and 11) compared to high Cd cultivars.

The root Cd concentration in No. 12 (high-Cd) was always the highest among the five cultivars, whereas it was only $20.23 \%$ and $18.14 \%$ higher than that in No. 2 (low-Cd) in T2 and T3 treatments, respectively (Table 3). The shoot Cd concentration in No. 12 (high-
Cd) was also the highest among the five cultivars and was $184.65 \%$ and $207.55 \%$ higher than that in No. 2 (low-Cd) in T2 and T3 treatments, respectively (Table 3). Meanwhile, the variation of shoot and root $\mathrm{Pb}$ concentration between high- $\mathrm{Pb}$ cultivar and low$\mathrm{Pb}$ cultivar was similar to the phenomenon of $\mathrm{Cd}$ (Table 4), and there were no significant correlations $(p<0.05)$ between the fruit $\mathrm{Cd}$ and $\mathrm{Pb}$ concentrations 
Table 3. Concentrations of Cd (dry mass, DW) in roots, shoots (leaves and stems) and fruits of hot pepper cultivars under four Cd and $\mathrm{Pb}$ treatments (control, $\mathrm{T} 1, \mathrm{~T} 2$ and $\mathrm{T} 3$ ),

\begin{tabular}{|c|c|c|c|c|}
\hline Cultivar No. & Treatments & Roots $\mathrm{Cd}$ concentration & Shoots $\mathrm{Cd}$ concentration & Fruits $\mathrm{Cd}$ concentration \\
\hline \multirow{4}{*}{$\begin{array}{l}\text { 2-Low Cd } \\
\text { Cultivar }\end{array}$} & Control & $0.93 \pm 0.056 \mathrm{e}$ & $0.35 \pm 0.047 \mathrm{i}$ & $0.072 \pm 0.009 \mathrm{c}$ \\
\hline & $\mathrm{T} 1$ & $1.19 \pm 0.15 \mathrm{e}$ & $0.42 \pm 0.036 \mathrm{i}$ & $0.07 \pm 0.005 \mathrm{c}$ \\
\hline & $\mathrm{T} 2$ & $5.48 \pm 0.31 \mathrm{~d}$ & $2.15 \pm 0.20 \mathrm{~g}$ & $0.22 \pm 0.031 \mathrm{~b}$ \\
\hline & $\mathrm{T} 3$ & $13.01 \pm 1.91 \mathrm{~b}$ & $5.03 \pm 0.42 \mathrm{de}$ & $2.31 \pm 0.12 \mathrm{a}$ \\
\hline \multirow{4}{*}{$\begin{array}{l}\text { 8-Low Cd } \\
\text { Cultivar }\end{array}$} & Control & $0.87 \pm 0.026 \mathrm{e}$ & $0.32 \pm 0.035 \mathrm{i}$ & $0.073 \pm 0.011 \mathrm{~b}$ \\
\hline & $\mathrm{T} 1$ & $1.48 \pm 0.06 \mathrm{e}$ & $0.57 \pm 0.085 \mathrm{hi}$ & $0.068 \pm 0.01 \mathrm{~b}$ \\
\hline & $\mathrm{T} 2$ & $6.04 \pm 0.22 \mathrm{~cd}$ & $2.63 \pm 0.50 \mathrm{fg}$ & $0.21 \pm 0.03 b$ \\
\hline & $\mathrm{T} 3$ & $12.73 \pm 1.53 b$ & $5.08 \pm 0.18 \mathrm{de}$ & $2.62 \pm 0.24 \mathrm{a}$ \\
\hline \multirow{4}{*}{$\begin{array}{l}\text { 11-Low Cd } \\
\text { Cultivar }\end{array}$} & Control & $0.82 \pm 0.042 \mathrm{e}$ & $0.45 \pm 0.078 \mathrm{hi}$ & $0.091 \pm 0.008 \mathrm{c}$ \\
\hline & $\mathrm{T} 1$ & $1.32 \pm 0.085 \mathrm{e}$ & $0.56 \pm 0.03 \mathrm{hi}$ & $0.12 \pm 0.023 \mathrm{c}$ \\
\hline & $\mathrm{T} 2$ & $7.47 \pm 0.47 \mathrm{c}$ & $3.34 \pm 0.50 \mathrm{f}$ & $0.39 \pm 0.029 b$ \\
\hline & T3 & $14.8 \pm 1.51 \mathrm{a}$ & $7.31 \pm 0.69 c$ & $2.51 \pm 0.14 \mathrm{a}$ \\
\hline \multirow{4}{*}{$\begin{array}{l}\text { 5-High Cd } \\
\text { Cultivar }\end{array}$} & Control & $0.96 \pm 0.082 \mathrm{e}$ & $0.57 \pm 0.09 \mathrm{hi}$ & $0.17 \pm 0.023 c$ \\
\hline & $\mathrm{T} 1$ & $1.61 \pm 0.12 \mathrm{e}$ & $1.03 \pm 0.10 \mathrm{hi}$ & $0.25 \pm 0.031 b c$ \\
\hline & $\mathrm{T} 2$ & $6.48 \pm 0.39 \mathrm{~cd}$ & $4.77 \pm 0.54 \mathrm{e}$ & $0.54 \pm 0.053 b$ \\
\hline & T3 & $14.52 \pm 2.06 \mathrm{a}$ & $9.92 \pm 1.07 \mathrm{~b}$ & $2.67 \pm 0.40 \mathrm{a}$ \\
\hline \multirow{4}{*}{$\begin{array}{l}\text { 12-High Cd } \\
\text { Cultivar }\end{array}$} & Control & $1.03 \pm 0.08 \mathrm{e}$ & $0.67 \pm 0.12 \mathrm{hi}$ & $0.19 \pm 0.021 \mathrm{c}$ \\
\hline & $\mathrm{T} 1$ & $1.58 \pm 0.16 \mathrm{e}$ & $1.53 \pm 0.14 \mathrm{gh}$ & $0.28 \pm 0.017 \mathrm{c}$ \\
\hline & $\mathrm{T} 2$ & $6.59 \pm 0.64 \mathrm{~cd}$ & $6.12 \pm 0.51 \mathrm{~d}$ & $0.58 \pm 0.085 b$ \\
\hline & $\mathrm{T} 3$ & $15.37 \pm 1.58 \mathrm{a}$ & $15.47 \pm 2.42 \mathrm{a}$ & $3.82 \pm 0.23 \mathrm{a}$ \\
\hline
\end{tabular}

Note: 1. Data in the table is shown as mean \pm standard deviation $(n=3) ; 2$. Different letters (a,b,c,d, e, etc.) refer to significant differences at the 0.05 level. (Total samples $N=160$; Replication $n=3$ )

and the root $\mathrm{Cd}$ and $\mathrm{Pb}$ concentrations (Table 5). Therefore, the possible reason for the higher fruit $\mathrm{Cd}$ and $\mathrm{Pb}$ concentrations in high $\mathrm{Cd}$ and $\mathrm{Pb}$ cultivars is that the high $(\mathrm{Cd}$ and $\mathrm{Pb})$ cultivars increased the ability to absorb $\mathrm{Cd}$ and $\mathrm{Pb}$ through its roots and shoots, especially the shoots being more important, which were influenced the plant genotype, the bioavailability of heavy metals, and plant metabolic pattern [15, 41]. Although Xue et al. [42] also found that low-Cd pakchoi (Brassica chinensis L.) cultivar 'AJKSHY' and 'BMG' had a higher $\mathrm{Cd}$ concentration in the roots than the high Cd cultivar 'SYM' and 'AJSZQ', no significant difference in root $\mathrm{Cd}$ concentrations was found among the four cultivars. Similarly, no significant differences of root $\mathrm{Cd}$ concentrations in low $\mathrm{Cd}$ rice cultivar 'Sasanishiki' and the high Cd cultivar 'Habataki' were also reported by Uraguchi et al. [43]. These results indicated that the $\mathrm{Cd}$ and $\mathrm{Pb}$ uptake in roots is not a major factor determining the significant difference in fruit $\mathrm{Cd}$ and $\mathrm{Pb}$ concentrations between high and low $\mathrm{Cd}$ and $\mathrm{Pb}$ hot pepper cultivars. Therefore, the $\mathrm{Cd}$ and $\mathrm{Pb}$ concentrations in hot pepper fruits is less correlation with root $\mathrm{Cd}$ and $\mathrm{Pb}$ concentrations compared to the shoot $\mathrm{Cd}$ and $\mathrm{Pb}$ concentrations (Table 5).

\section{$\mathrm{Cd}$ and $\mathrm{Pb}$ Translocation}

The translocation factor is calculated as the ratio of the $\mathrm{Cd}$ and $\mathrm{Pb}$ concentrations in plant aboveground parts to the $\mathrm{Cd}$ and $\mathrm{Pb}$ concentrations in plant roots, which indicated the capacity of plants to translocate $\mathrm{Cd}$ and $\mathrm{Pb}$ from roots to aboveground parts [44]. In this study, low $\mathrm{Cd}$ and $\mathrm{Pb}$ cultivars always had a lower translocation factor than the two high $\mathrm{Cd}$ and $\mathrm{Cd}$ cultivars (Fig. 3). This result shows that low $\mathrm{Cd}$ and $\mathrm{Pb}$ cultivars may have a greater ability to detain $\mathrm{Cd}$ in roots compared with high $\mathrm{Cd}$ and $\mathrm{Pb}$ cultivars. Meanwhile, the root $\mathrm{Cd}$ and $\mathrm{Pb}$ concentrations in the high $\mathrm{Cd}$ and $\mathrm{Pb}$ cultivars were not significant differences $(p<0.05)$ compared to the low $\mathrm{Cd}$ and $\mathrm{Pb}$ cultivars; however, greater $\mathrm{Cd}$ and $\mathrm{Pb}$ translocation factors were observed in high $\mathrm{Cd}$ and $\mathrm{Pb}$ cultivars, respectively (Fig. 3). In addition, significant positive relationships $(p<0.05)$ were also found between fruit $\mathrm{Cd}$ and $\mathrm{Pb}$ concentrations 
Table 4. Concentrations of $\mathrm{Pb}$ (dry mass, $\mathrm{DW}$ ) in roots, shoots (leaves and stems) and fruits of pepper cultivars under four $\mathrm{Cd}$ and $\mathrm{Pb}$ treatments (control, T1, T2 and T3).

\begin{tabular}{|c|c|c|c|c|}
\hline Cultivar No. & Treatments & Roots $\mathrm{Pb}$ concentration & Shoots $\mathrm{Pb}$ concentration & Fruits $\mathrm{Pb}$ concentration \\
\hline \multirow{4}{*}{$\begin{array}{c}\text { 1-Low Pb } \\
\text { Cultivar }\end{array}$} & Control & $6.72 \pm 1.15 \mathrm{~g}$ & $1.14 \pm 0.11 \mathrm{~h}$ & $0.073 \pm 0.009 \mathrm{~h}$ \\
\hline & $\mathrm{T} 1$ & $68.95 \pm 9.30 \mathrm{f}$ & $34.58 \pm 5.84 \mathrm{fg}$ & $0.24 \pm 0.032 \mathrm{~h}$ \\
\hline & $\mathrm{T} 2$ & $216.18 \pm 13.18 \mathrm{de}$ & $130.56 \pm 11.76 \mathrm{~cd}$ & $0.54 \pm 0.031 \mathrm{gh}$ \\
\hline & $\mathrm{T} 3$ & $303.64 \pm 25.23 b$ & $132.96 \pm 9.07 \mathrm{~cd}$ & $11.1 \pm 1.62 \mathrm{c}$ \\
\hline \multirow{4}{*}{$\begin{array}{c}\text { 6-Low Pb } \\
\text { Cultivar }\end{array}$} & Control & $5.77 \pm 0.68 \mathrm{~g}$ & $0.93 \pm 0.071 \mathrm{~h}$ & $0.067 \pm 0.015 \mathrm{~h}$ \\
\hline & $\mathrm{T} 1$ & $67.52 \pm 6.54 f$ & $36.25 \pm 2.01 \mathrm{fg}$ & $0.25 \pm 0.023 \mathrm{~h}$ \\
\hline & $\mathrm{T} 2$ & $206.18 \pm 22.33 \mathrm{de}$ & $120.67 \pm 15.34 \mathrm{cde}$ & $0.53 \pm 0.027 \mathrm{gh}$ \\
\hline & $\mathrm{T} 3$ & $315.06 \pm 26.82 b$ & $147.16 \pm 4.14 \mathrm{c}$ & $9.93 \pm 1.29 \mathrm{~d}$ \\
\hline \multirow{4}{*}{$\begin{array}{c}\text { 8-Low Pb } \\
\text { Cultivar }\end{array}$} & Control & $4.77 \pm 0.54 \mathrm{~g}$ & $0.64 \pm 0.056 \mathrm{~h}$ & $0.042 \pm 0.006 \mathrm{~h}$ \\
\hline & $\mathrm{T} 1$ & $65.79 \pm 7.02 \mathrm{f}$ & $30.55 \pm 2.78 \mathrm{gh}$ & $0.13 \pm 0.017 \mathrm{~h}$ \\
\hline & $\mathrm{T} 2$ & $230.2 \pm 19.55 \mathrm{~d}$ & $122.69 \pm 9.96 \mathrm{cde}$ & $0.44 \pm 0.051 \mathrm{gh}$ \\
\hline & $\mathrm{T} 3$ & $305.26 \pm 16.05 b$ & $118.99 \pm 15.19 \mathrm{cde}$ & $7.67 \pm 0.68 \mathrm{e}$ \\
\hline \multirow{4}{*}{$\begin{array}{l}\text { 11-Low Pb } \\
\text { Cultivar }\end{array}$} & Control & $5.44 \pm 0.88 \mathrm{~g}$ & $0.77 \pm 0.10 \mathrm{~h}$ & $0.046 \pm 0.01 \mathrm{~h}$ \\
\hline & $\mathrm{T} 1$ & $69.52 \pm 7.30 \mathrm{f}$ & $30.53 \pm 1.33 \mathrm{gh}$ & $0.12 \pm 0.02 \mathrm{~h}$ \\
\hline & $\mathrm{T} 2$ & $199.23 \pm 11.11 \mathrm{de}$ & $98.08 \pm 7.46 \mathrm{e}$ & $0.53 \pm 0.049 \mathrm{gh}$ \\
\hline & $\mathrm{T} 3$ & $321.19 \pm 33.60 \mathrm{~b}$ & $104.88 \pm 15.98 \mathrm{de}$ & $9.83 \pm 1.4 \mathrm{~d}$ \\
\hline \multirow{4}{*}{$\begin{array}{c}\text { 3-High } \mathrm{Pb} \\
\text { Cultivar }\end{array}$} & Control & $6.59 \pm 0.76 \mathrm{~g}$ & $1.49 \pm 0.19 \mathrm{~h}$ & $0.13 \pm 0.021 \mathrm{~h}$ \\
\hline & $\mathrm{T} 1$ & $72.76 \pm 5.96 f$ & $53.52 \pm 5.45 \mathrm{fg}$ & $0.38 \pm 0.047 \mathrm{gh}$ \\
\hline & $\mathrm{T} 2$ & $226.89 \pm 24.31 \mathrm{de}$ & $293.87 \pm 32.2 b$ & $1.4 \pm 0.26 \mathrm{fg}$ \\
\hline & $\mathrm{T} 3$ & $332.17 \pm 22.81 b$ & $349.25 \pm 43.49 a$ & $16.49 \pm 0.63 b$ \\
\hline \multirow{4}{*}{$\begin{array}{l}\text { 12-High Pb } \\
\text { Cultivar }\end{array}$} & Control & $7.17 \pm 0.78 \mathrm{~g}$ & $1.89 \pm 0.17 \mathrm{~h}$ & $0.12 \pm 0.02 \mathrm{~h}$ \\
\hline & $\mathrm{T} 1$ & $80.43 \pm 7.02 \mathrm{f}$ & $65.10 \pm 6.51 \mathrm{f}$ & $0.56 \pm 0.017 \mathrm{gh}$ \\
\hline & $\mathrm{T} 2$ & $261.56 \pm 28.63 \mathrm{c}$ & $365.30 \pm 59.29 \mathrm{a}$ & $1.76 \pm 0.2 \mathrm{f}$ \\
\hline & $\mathrm{T} 3$ & $367.77 \pm 45.24 \mathrm{a}$ & $368.12 \pm 26.86 \mathrm{a}$ & $19.51 \pm 1.67 \mathrm{a}$ \\
\hline
\end{tabular}

Note: 1 . Data in the table is shown as mean \pm standard deviation $(n=3) ; 2$. Different letters $(a, b, c, d, e$, etc.) refer to significant differences at the 0.05 level. (Total samples $\mathrm{N}=160$; Replication $\mathrm{n}=3$ )

to $\mathrm{Cd}$ and $\mathrm{Pb}$ translocation factors (Table 5), suggesting that translocation ability is an important factor that can affect $\mathrm{Cd}$ and $\mathrm{Pb}$ accumulation in fruits. This may be attributed to the fact that movement of $\mathrm{Cd}$ and $\mathrm{Pb}$ into fruits probably occurs via phloem, which is a process of retranslocation from shoots (stems and leaves) to fruits [40]. Liu et al. [13] investigated the translocation factor of low- and high-Cd Chinese cabbage (Brassica pekinensis (Lour.) Rupr.) cultivars, and found that the translocation factor was highly correlated with the concentration in edible plant parts of Chinese cabbage cultivars. In the present study, significant $(p<0.05)$

Table. 5. Relationships, given as $\mathrm{r}$ values $(\mathrm{n}=15(\mathrm{Cd})$ and $18(\mathrm{~Pb}))$, between hot pepper fruit $\mathrm{Cd}$ and $\mathrm{Pb}$ concentrations and the $\mathrm{Cd}$ and $\mathrm{Pb}$ concentrations in shoots and roots, and $\mathrm{Cd}$ and $\mathrm{Pb}$ translocation factors under different treatments (significant at $P<0.05$ ).

\begin{tabular}{|c|c|c|c|c|c|c|}
\hline \multirow{2}{*}{ Treatments } & \multicolumn{2}{|c|}{ Root concentration } & \multicolumn{2}{c|}{ Shoot concentration } & \multicolumn{2}{c|}{ Translocation factor } \\
\cline { 2 - 7 } & $\mathrm{Cd}$ & $\mathrm{Pb}$ & $\mathrm{Cd}$ & $\mathrm{Pb}$ & $\mathrm{Cd}$ & $\mathrm{Pb}$ \\
\hline $\mathrm{T} 1$ & 0.706 & 0.585 & $0.916^{*}$ & $0.915^{*}$ & $0.934^{*}$ & $0.837^{*}$ \\
\hline $\mathrm{T} 2$ & 0.428 & 0.633 & $0.935^{*}$ & $0.920^{*}$ & $0.879^{*}$ & $0.823^{*}$ \\
\hline $\mathrm{T} 3$ & 0.287 & 0.625 & $0.808^{*}$ & $0.939^{*}$ & $0.764^{*}$ & $0.895^{*}$ \\
\hline
\end{tabular}


a)

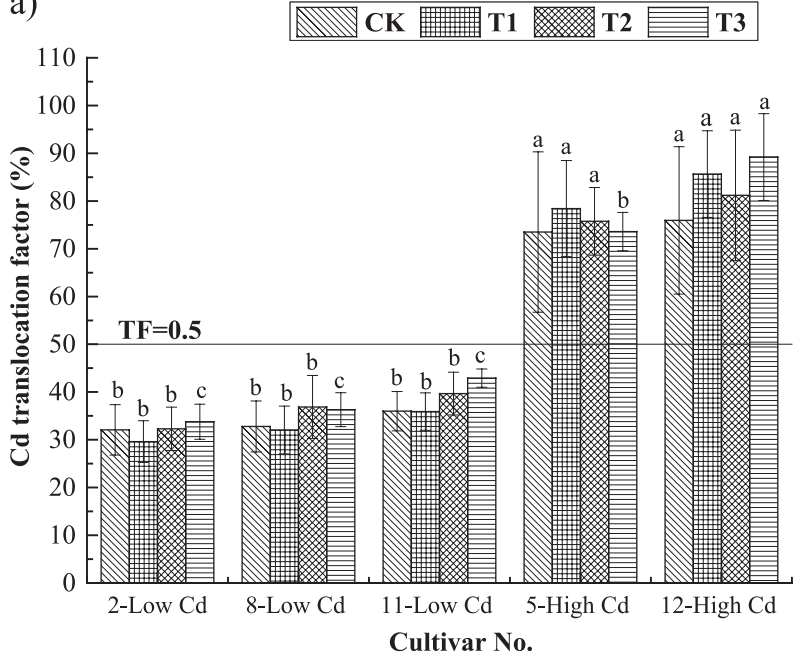

b)

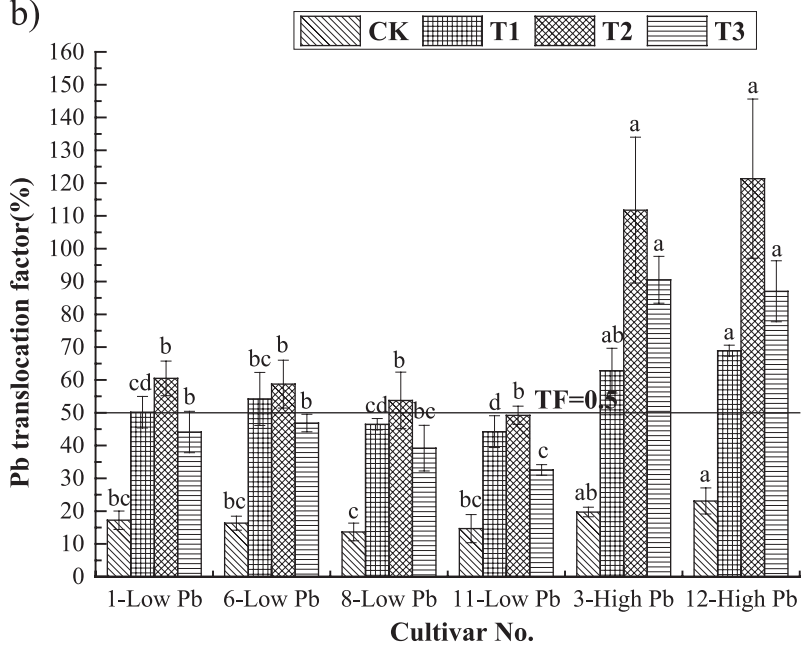

Fig. 3. Difference of translocation factor in low- Cd (a) and $-\mathrm{Pb}(\mathrm{b})$ and high-Cd (a) and $-\mathrm{Pb}(\mathrm{b})$ hot pepper cultivars under four $\mathrm{Cd}$ and $\mathrm{Pb}$ treatments (control, T1, T2 and T3); lowercase letters indicate significant differences among different cultivars in identical $\mathrm{Cd}$ and $\mathrm{Pb}$ treatments $(p<0.05$; total samples $\mathrm{N}=160$; replication $\mathrm{n}=3$ ); $\mathrm{Y}$ line indicates the value of translocation factor $(\mathrm{Y}=0.5)$.

positive correlation was also found between the $\mathrm{Cd}$ and $\mathrm{Pb}$ concentrations in fruits and in shoots (Table 5). Nevertheless, the determination of whether the stem or leaf provides a bigger contribution to $\mathrm{Cd}$ and $\mathrm{Pb}$ concentration in fruits of hot pepper still needs more experimentation.

\section{Conclusions}

The results of the present study indicate that the ability to accumulate $\mathrm{Cd}$ and $\mathrm{Pb}$ in fruits are significant differences among the hot pepper cultivars $(p<0.5)$. Hot pepper cultivars Nos. 8 (Youma) and 11 (Xianglaerjintiao) were selected as low $\mathrm{Cd}$ and $\mathrm{Pb}$ cultivars in this study. Nevertheless, the nitrate content of No. 11 (Xianglaerjintiao) exceeded $440 \mathrm{mg} \cdot \mathrm{kg}^{-1}$ FW, thus No. 11 (Xianglaerjintiao) can be grown to increase food safety compare to No. 8 (Youma). The differences in fruit $\mathrm{Cd}$ and $\mathrm{Pb}$ concentrations between low and high cultivars were owing to variations of $\mathrm{Cd}$ and $\mathrm{Pb}$ translocation factors and shoot $\mathrm{Cd}$ and $\mathrm{Pb}$ concentrations rather than to the roots $\mathrm{Cd}$ concentration. In addition, further experiments should be conducted to demonstrate whether the accumulation of heavy metal $(\mathrm{Cd}$ and $\mathrm{Pb})$ in hot pepper fruits mainly originates from phloem transport or xylem transport, which is conducive to breeding for low $\mathrm{Cd}$ and $\mathrm{Pb}$ cultivars.

\section{Acknowledgements}

Our study was funded by the Sichuan Science and Technology Program, China (No. 2018HH0137).

\section{Conflict of Interest}

The authors declare that they have no competing interests.

\section{References}

1. SHAHEEN N., IRFAN N.M., KHAN I.N., ISLAM S., ISLAM M.S., AHMED M.K. Presence of heavy metals in fruits and vegetables: Health risk implications in Bangladesh. Chemosphere, 152, 431, 2016.

2. ANTONIADIS V., SHAHEEN S.M., LEVIZOU E., SHAHID M., NIAZI N.K., VITHANAGE M., OK Y.S., BOLAN, N., RINKLEBE J. A critical prospective analysis of the potential toxicity of trace element regulation limits in soils worldwide: Are they protective concerning health risk assessment? - A review. Environment International, 127, 819, 2019.

3. LU L., LI J., HU A., MULLA S., YANG J., YU C.P. Microbial community structure analysis and isolation of vanadium-resistant strains in vanadium mining-impacted soil. Journal of Soil and Water Conservation, 74 (3), 296, 2019.

4. ZHAO F.J., MA Y., ZHU Y.G., TANG Z., MCGRATH S.P. Soil Contamination in China: Current Status and Mitigation Strategies. Environmental Science \& Technology, 49(2), 750, 2015.

5. ZHANG H., GUO Q., YANG J., MA J., CHEN G., CHEN T., ZHU G., WANG J., ZHANG G., WANG X., SHAO C. Comparison of chelates for enhancing Ricinus communis $\mathrm{L}$. phytoremediation of $\mathrm{Cd}$ and $\mathrm{Pb}$ contaminated soil. Ecotoxicology and Environmental Safety, 133, 57, 2016.

6. BOPARAI H.K., JOSEPH M., O'CARROLL D.M. Kinetics and thermodynamics of cadmium ion removal by adsorption noto nano zerovalent iron particles. Journal of Hazardous Materials, 186 (1), 458, 2011.

7. FAHMI A.H., SAMSURI A.W., JOL H., SINGH D. Bioavailability and leaching of $\mathrm{Cd}$ and $\mathrm{Pb}$ from contaminated soil amended with different sizes of biochar. Royal Society Open Science, 5 (11), 181328, 2018.

8. WANG L., HUANG L., XIA H., LI H., LI X., LIU X. Application of a multi-electrode system with polyaniline auxiliary electrodes for electrokinetic remediation of 
chromium-contaminated soil. Separation and Purification Technology, 224, 106, 2019.

9. LIU W., ZHOU Q., AN J., SUN Y., LIU R. Variations in cadmium accumulation among Chinese cabbage cultivars and screening for Cd-safe cultivars. Journal of Hazardous Materials, 173 (1-3), 737, 2010.

10. XU Z. M., TAN X.Q., MEI X.Q., LI Q.S., ZHOU C., WANG L.L.,YE H.J., YANG P. Low-Cd tomato cultivars (Solanum lycopersicum L.) screened in non-saline soils also accumulated low $\mathrm{Cd}, \mathrm{Zn}$, and $\mathrm{Cu}$ in heavy metalpolluted saline soils. Environmental Science and Pollution Research, 25 (27) 27439, 2018.

11. ZHANG K., YUAN J., KONG W., YANG Z. Genotype variations in cadmium and lead accumulations of leafy lettuce (Lactuca sativa L.) and screening for pollution-safe cultivars for food safety. Environmental Science: Processes \& Impacts, 15 (6), 1245, 2013.

12. LI X., ZHOU Q., WEI S., REN W. Identification of cadmium-excluding welsh onion (Allium fistulosum L.) cultivars and their mechanisms of low cadmium accumulation. Environmental Science and Pollution Research, 19 (5), 1773, 2012.

13. LIU W., ZHOU Q., SUN Y., LIU R. Identification of Chinese cabbage genotypes with low cadmium accumulation for food safety. Environmental Pollution, 157 (6), 1961, 2009.

14. ZHANG Z., JIN F., WANG C., LUO J., LIN H., XIANG K., LIU L., ZHAO M., ZHANG Y., DING H., ZHOU S., SHEN Y., PAN, G. Difference between $\mathrm{Pb}$ and $\mathrm{Cd}$ Accumulation in 19 Elite Maize Inbred Lines and Application Prospects. Journal of Biomedicine and Biotechnology, 2012, 1, 2012.

15. LIU W., LIANG L., ZHANG X., ZHOU Q. Cultivar variations in cadmium and lead accumulation and distribution among 30 wheat (Triticum aestivum L.) cultivars. Environmental Science and Pollution Research, 22 (11), 8432, 2015.

16. WU Z., WU W., ZHOU S., WU S. Mycorrhizal Inoculation Affects $\mathrm{Pb}$ and $\mathrm{Cd}$ Accumulation and Translocation in Pakchoi (Brassica chinensis L.). Pedosphere, 26 (1), 13, 2016.

17. ZHOU Y., XUE M., YANG Z., GONG Y., YUAN J., ZHOU C., HUANG B. High cadmium pollution risk on vegetable amaranth and a selection for pollution-safe cultivars to lower the risk. Frontiers of Environmental Science \& Engineering, 7 (2), 219, 2013.

18. LIU B.Q., WU F.F., DAI X.Z., LIU F., MI B.L. Variations of Cadmium Accumulation and Translocation in Different Pakchoi Cultivars and Screening for Cd-Pollution-Safe Cultivars Using Cluster Analysis. Polish Journal of Environmental Studies, 28 (4), 2215, 2019.

19. SU Y., WANG X., LIU C., SHI G. Variation in cadmium accumulation and translocation among peanut cultivars as affected by iron deficiency. Plant and Soil, 363 (1-2), 201, 2013.

20. HAGHIGHI M., KAFI M., PESSARAKLI M., SHEIBANIRAD A., SHARIFINIA M.R. Using kale (Brassica oleraceavar. acephala) as a phytoremediation plant species for lead $(\mathrm{Pb})$ and cadmium $(\mathrm{Cd})$ removal in saline soils. Journal of Plant Nutrition, 39 (10), 1460, 2016.

21. TANG L., HAMID Y., ZEHRA A., SAHITO Z.A., HE Z., HUSSAIN B., GURAJALA H.K., YANG X. Characterization of fava bean (Vicia faba L.) genotypes for phytoremediation of cadmium and lead co-contaminated soils coupled with agro-production. Ecotoxicology and Environmental Safety, 171, 190, 2019.
22. HORD N.G., TANG Y., BRYAN N.S. Food sources of nitrates and nitrites: the physiologic context for potential health benefits. The American Journal of Clinical Nutrition, 90 (1), 1, 2009.

23. CORRADINI F., CORREA A., MOYANO M.S., SEPÚLVEDA P., QUIROZ C. Nitrate, arsenic, cadmium, and lead concentrations in leafy vegetables: expected average values for productive regions of Chile. Archives of Agronomy and Soil Science, 64 (3), 299, 2017.

24. DELlaVAlle C.T., XIAO Q., YANG G., SHU X.O., ASCHEBROOK-KILFOY B., ZHENG W., LI H., JI B.T., ROTHMAN N., CHOW W.H., GAO Y.T., WARD M.H. Dietary nitrate and nitrite intake and risk of colorectal cancer in the Shanghai Women's Health Study. International Journal of Cancer, 134 (12), 2917, 2014.

25. ANTONIOUS G.F. Distribution of seven heavy metals among hot pepper plant parts. Journal of Environmental Science and Health Part b, 51 (5), 309, 2016.

26. CHEN L., LONG C., WANG D., YANG J. Phytoremediation of cadmium (Cd) and uranium (U) contaminated soils by Brassica juncea L. enhanced with exogenous application of plant growth regulators. Chemosphere, 242, 125112, 2020.

27. JOHN R., AHMAD P., GADGIL K., SHARMA S. Cadmium and lead-induced changes in lipid peroxidation, antioxidative enzymes and metal accumulation in Brassica juncea L. at three different growth stages. Archives of Agronomy and Soil Science, 55 (4), 395, 2009.

28. CHEN Y., LI T., HAN X., DING Z., YAN X., JIN Y. Cadmium accumulation in different pakchoi cultivars and screening for pollution-safe cultivars. Journal of Zhejiang University-SCIENCE B, 13 (7), 494, 2012.

29. PILON-SMITS E.A., QUINN C.F., TAPKEN W., MALAGOLI M., SCHIAVON M. Physiological functions of beneficial elements. Current Opinion in Plant Biology, 12 (3), 267, 2009

30. POSCHENRIEDER C., CABOT C., MARTOS S., GALLEGO B., BARCELÓ J. Do toxic ions induce hormesis in plants? Plant Science, 212, 15, 2013.

31. XIN J., HUANG B., LIU A., ZHOU W., LIAO K. Identification of hot pepper cultivars containing low $\mathrm{Cd}$ levels after growing on contaminated soil: uptake and redistribution to the edible plant parts. Plant and Soil, 373 (1-2), 415, 2013.

32. NYITRAI P., BÓKA K., GÁSPÁR L., SÁRVÁRI É., KERESZTES Á. Rejuvenation of Ageing Bean Leaves under the Effect of Low-Dose Stressors. Plant Biology, 6 (6), 708, 2004.

33. IAMMARINO M., DI TARANTO A., CRISTINO M. Monitoring of nitrites and nitrates levels in leafy vegetables (spinach and lettuce): a contribution to risk assessment. Journal of the Science of Food and Agriculture, 94 (4), 773, 2014

34. LI S., LI J., ZHANG B., LI D., LI G., LI Y. Effect of different organic fertilizers application on growth and environmental risk of nitrate under a vegetable field. Scientific Reports, 7, 17020, 2017.

35. WEI C.X., ZHANG X. Effects of Zinc lead and cadmium contamination on nitrate contents in pakchoi. Journal of Southwest University, 27 (4), 436, 2005.

36. DEMIRAL M.A., AY M., SORAL F., TEKIN M. Effect of nitrogen on growth and nitrate accumulation of some leafy vegetables. Journal of Adnan Menderes University, Agricultural Faculty, 6 (2), 3, 2009.

37. CAO F., WANG R., CHENG W., ZENG F., AHMED I.M., HU X., ZHANG G., WU F. Genotypic and environmental 
variation in cadmium, chromium, lead and copper in rice and approaches for reducing the accumulation. Science of The Total Environment, 496, 275, 2014.

38. WANG X., BAI J., WANG J., LE S., WANG M., ZHAO Y. Variations in cadmium accumulation and distribution among different oilseed rape cultivars in Chengdu Plain in China. Environmental Science and Pollution Research, 26 (4), 3415, 2019.

39. DING C., ZHANG T., WANG X., ZHOU F., YANG Y., YIN Y. Effects of soil type and genotype on lead concentration in rootstalk vegetables and the selection of cultivars for food safety. Journal of Environmental Management, 122, 8, 2013.

40. HUANG B., XIN J., DAI H., ZHOU W., PENG L. Identification of low-Cd cultivars of sweet potato (Ipomoea batatas (L.) Lam.) after growing on Cd-contaminated soil: uptake and partitioning to the edible roots. Environmental Science and Pollution Research, 22 (15), 11813, 2015.

41. ZHU Y., YU H., WANG J., FANG W., YUAN J., YANG
Z. Heavy Metal Accumulations of 24 Asparagus Bean Cultivars Grown in Soil Contaminated with $\mathrm{Cd}$ Alone and with Multiple Metals $(\mathrm{Cd}, \mathrm{Pb}$, and $\mathrm{Zn})$. Journal of Agricultural and Food Chemistry, 55 (3), 1045, 2017.

42. XUE M., ZHOU Y., YANG Z., LIN B., YUAN J., WU $\mathrm{S}$. Comparisons in subcellular and biochemical behaviors of cadmium between low-Cd and high-Cd accumulation cultivars of pakchoi (Brassica chinensis L.). Frontiers of Environmental Science \& Engineering, 8 (2), 226, 2014.

43. URAGUCHI S., MORI S., KURAMATA M., KAWASAKI A., ARAO T., ISHIKAWA S. Root-toshoot $\mathrm{Cd}$ translocation via the xylem is the major process determining shoot and grain cadmium accumulation in rice. Journal of Experimental Botany, 60 (9), 2677, 2009.

44. AFONSO T.F., DEMARCO C.F., PIENIZ S., CAMARGO F.A.O., QUADRO M.S., ANDREAZZA R. Potential of Solanum viarum Dunal in use for phytoremediation of heavy metals to mining areas, southern Brazil. Environmental Science and Pollution Research, 26 (23), $24132,2019$. 
